\title{
Estrogen receptor- $\alpha$ mediates gene expression changes and growth response in ovarian cancer cells exposed to estrogen
}

\author{
Amanda J M O'Donnell, Kenneth G Macleod, David J Burns, \\ John F Smyth and Simon P Langdon
}

Cancer Research UK Centre, University of Edinburgh, Crewe Road South, Edinburgh EH4 2XR, UK

(Requests for offprints should be addressed to S Langdon; Email: simon.langdon@cancer.org.uk)

\begin{abstract}
Estrogens play a significant role in the development, growth, invasion and metastasis of ovarian tumors. The transcriptional program regulated by $17 \beta$-estradiol $\left(E_{2}\right)$ in human ovarian cancer cell lines was analyzed using cDNA microarrays containing 1200 cancer-related genes. Twenty-eight transcripts had at least a threefold change in expression in $\mathrm{E}_{2}$-treated PEO1 ovarian carcinoma cells compared with controls. These differences were confirmed by real-time quantitative PCR and shown to be dependent upon the expression of functional estrogen receptor- $\alpha(E R \alpha)$. Consistent with this, these gene expression changes were blocked by the anti-estrogen tamoxifen. The use of $E R \alpha-$ and $E R \beta$-specific ligands allowed molecular dissection of the $E_{2}$ response and showed that $\mathrm{ER} \alpha$ activation was responsible for the observed changes in gene expression, whereas ER $\beta$ played no significant role. Inhibition of de novo protein synthesis by cycloheximide was used to distinguish between primary and secondary target genes regulated by $E_{2}$. Actinomycin $D$ was used to show that changes in gene expression levels induced by $E_{2}$ were a result of changes in transcription and not due to changes in mRNA stability. The results presented here demonstrate that estrogen-driven growth of epithelial ovarian carcinoma is mediated by activation of ER $\alpha$-mediated, and not ER $\beta$ mediated, transcription.
\end{abstract}

Endocrine-Related Cancer (2005) 12 851-866

\section{Introduction}

Epithelial ovarian carcinoma is the leading cause of death from gynecological malignancies in the Western world (Greenlee et al. 2000). This is mainly because most ovarian tumors are not diagnosed until in an advanced metastatic stage. Although various therapeutic approaches are followed in clinical practice, most of them are not life saving, and the majority of patients have only a $10-20 \%$ overall 5 -year survival rate (Boente et al. 1993). Insight into the molecular mechanisms involved in the etiology and progression of ovarian carcinoma is important when searching for new therapies to improve the outcome of patients with this disease.

Estrogens are major regulators of growth and differentiation in normal ovaries and in the development and progression of ovarian carcinoma, but the mechanisms of action remain unclear. The biological effects of estrogens are mediated by two forms of estrogen receptor (ER) that are encoded by separate genes, ER $\alpha$ and ER $\beta$ (Greene et al. 1985, Green et al. 1986, Ponglikitmongkol et al. 1988, Mosselman et al. 1996, Ogawa et al. 1998). The ER, a member of the nuclear receptor super-family, is an estrogen ligandactivated transcription factor that binds to an estrogen-responsive element (ERE) in the promoter region of target genes, regulating their transcription (Evans 1988, Green \& Chambon 1988). There has been much speculation about the relative roles of ER $\alpha$ and ER $\beta$ in this disease, as ER $\beta$ levels are high in the normal ovary and predominate over ER $\alpha$, while the converse is true in ovarian cancers (Brandenberger et al. 1997, Enmark et al. 1997, Kuiper et al. 1997, Pujol et al. 1998, Rutherford et al. 2000, Bardin et al. 2004, Lindgren et al. 2004). A recent study has suggested that $\mathrm{ER} \beta$ loss is an important event in the development of ovarian cancer (Bardin et al. 2004). In this report, 
we focus on the role of $E R \alpha$, the isoform that is retained in ovarian cancers.

The significance of estrogen in the etiology of ovarian carcinoma has been emphasized by the fact that anti-estrogenic intervention will inhibit the growth of ovarian carcinoma in vitro and in vivo (Langdon et al. 1990, 1994a), and recently it has been reported that estrogen replacement therapy induces ovarian cancer (Lacey et al. 2002). Clinical trials with the aromatase inhibitor letrozole, which acts by depleting levels of estrogen available to the ER, have shown clinical benefit in a sub-group of ovarian cancer patients (Bowman et al. 2002, Papadimitriou et al. 2004) as have trials using tamoxifen (Hatch et al. 1991, Ahlgren et al. 1993). These studies further support the view that certain ER-positive ovarian cancers show growth dependency on estrogen. As approximately two-thirds of all ovarian tumors express ER $\alpha$ at the time of diagnosis (Slotman \& Rao 1988), identifying the downstream targets of estrogen will reveal putative functional pathways regulated by activated ER, and provide a greater understanding of the roles estrogens play in ovarian cancer. Estrogen regulation of protein expression has been well documented in breast cancer models but to date little is known about estrogen-regulated gene expression in ovarian cancer. Genes which have been shown to be regulated, thus far, include c-myc (Chien et al. 1994, Hua et al. 1995), progesterone receptor (Nash et al. 1989, Langdon et al. 1994b), cathepsin D (CTSD) (GaltierDereure et al. 1992, Rowlands et al. 1993), fibulin-1 (Clinton et al. 1996, Moll et al. 2002) and insulin-like growth factor binding proteins (Krywicki et al. 1993).

Here we have used the BD Atlas Human Cancer Expression Array, containing 1200 gene probes, to monitor changes in gene expression in response to the naturally occurring estrogen 17-beta estradiol $\left(E_{2}\right)$, in an ER-positive, estrogen-responsive ovarian cancer cell line. The results reveal that $\mathrm{E}_{2}$ directly regulates the transcription of a plethora of genes involved in many aspects of cellular function such as DNA repair, extracellular matrix, apoptosis and signal transduction. Using a range of different cell lines and ER $\alpha$ - and ER $\beta$-specific ligands, we have been able to show that changes in gene expression are related to $E R \alpha$ status and hormone responsiveness.

\section{Materials and methods}

\section{Tissue culture}

The ovarian cancer cell lines, PEO1, PEO1 ${ }^{\mathrm{CDDP}}$, PEO4, PEO6, PEO14 and PEO16 were established within this unit (Langdon et al. 1988); SKOV-3, CaOV3 and MCF-7 cells were obtained from the American Type Culture Collection (Manassas, VA, USA); OVCAR-3, OVCAR-4 and OVCAR-5 were obtained from Dr T C Hamilton (Fox Chase Institute, Philadelphia, PA, USA); 41M, 59M, OAW42, A2780, ZR-75-1 and MDA-MB-231 cells were obtained from the European Collection of Cell Cultures (ECACC; Porton Down, Wilts, UK). All cell lines were routinely cultured at $37^{\circ} \mathrm{C}, 90 \%$ humidity and $5 \% \mathrm{CO}_{2}$ in RPMI 1640 (Life Technologies, Paisley, Strathclyde, UK) containing $10 \%$ heat-inactivated FCS, $100 \mu \mathrm{g} / \mathrm{ml}$ streptomycin and $100 \mathrm{IU} / \mathrm{ml}$ penicillin. Where specified, cells were treated with $25 \mu \mathrm{g} / \mathrm{ml}$ cycloheximide (Sigma, UK) to block protein synthesis, $5 \mu \mathrm{g} / \mathrm{ml}$ actinomycin D (Sigma, UK) to block transcription or $0.3 \mu \mathrm{M}$ tricostatin A (Calbiochem, La Jolla, CA, USA) to inhibit histone deacetylase activity. An ER $\alpha$ agonist (propyl pyrazole triol (PPT)) and an ER $\beta$-specific agonist (diarylpropionitrile (DPN)) were obtained from Tocris, Bristol, Avonmouth, UK and were used at the concentrations shown.

\section{Western blotting}

Cell lines were grown to $70 \%$ confluence in $92-\mathrm{cm}$ tissue culture dishes in the presence of RPMI 1640 containing 10\% FCS. The medium was removed and replaced with RPMI 1640 without phenol red but containing 5\% double charcoal-stripped FCS (DCSFCS). After a further $48-72 \mathrm{~h}$, estradiol $(1 \mathrm{nM})$ was added to cells. To harvest, cells were washed twice in ice-cold PBS, and lyzed in $50 \mathrm{mM}$ Tris $\mathrm{pH} 7.5$, $150 \mathrm{mM} \mathrm{NaCl}, 1 \% \mathrm{NP}-40,0.5 \mathrm{mM}$ EDTA, $2 \mathrm{mM}$ $\mathrm{Na}_{3} \mathrm{VO}_{4}, 10 \mathrm{mM} \mathrm{NaOMb}, 150 \mathrm{mM} \quad \mathrm{NaF}, 10 \mu \mathrm{g} / \mathrm{ml}$ aprotinin, $10 \mu \mathrm{g} / \mathrm{ml}$ leupeptin, $0.5 \mathrm{mM}$ dithiothreitol, and spun for $20 \mathrm{~min}$ at $16000 \mathrm{~g}$ at $4^{\circ} \mathrm{C}$. The protein content of the resulting supernatant was determined by the Bradford assay (Bio-Rad Laboratories, UK). Total protein $(5-30 \mu \mathrm{g})$ was separated on $10 \%$ SDSacrylamide gel and transferred onto a nitrocellulose membrane. Membranes were blocked in Tris-buffered saline ( $\mathrm{pH}$ 7.4) containing $0.1 \%$ Tween (TBST) and $10 \%$ milk. Blots were incubated in antibodies for $1 \mathrm{~h}$ at room temperature. The following antibodies were used: anti-ER $\alpha(1: 200$; Santa Cruz Biotechnology, Santa Cruz, CA, USA), anti-ER $\beta$ (1:500; Upstate Biotechnology, Lake Placid, NY, USA), and anti-fibronectin, (1:200; Santa Cruz Biotechnology). Immunoreactive bands were detected by enhanced chemiluminescence (Santa Cruz Biotechnology). 


\section{Growth assays}

Exponentially growing cells were harvested by trypsinization and plated in 24-well plates at a density of $5 \times 10^{4}$ cells/well in RPMI 1640 containing $10 \%$ FCS. After $24 \mathrm{~h}$ to allow for attachment, the medium was removed and replaced with RPMI 1640 without phenol red and 5\% DCS-FCS; $\mathrm{E}_{2}$ and tamoxifen were added to cells, and this was designated day 0. Cells were harvested from wells on day 5 and counted on a cell counter (Coulter Electronics Ltd, Luton, UK). Changes in growth were calculated relative to controls incubated in DCS-FCS-containing media.

\section{Oligonucleotide array}

Differential gene expression was performed using the Atlas Cancer 1.2 K cDNA Expression Array (BD, Palo Alto, CA, USA), according to the manufacturer's protocol.

\section{cDNA synthesis}

Total cellular RNA was extracted from cells in log phase growth using TRI reagent (Sigma, UK). RNA from each $75-\mathrm{cm}^{2}$ flask was treated with 20 units DNase 1 (Roche, East Sussex, UK), in $50 \mu$ l, to remove genomic DNA contamination. Forty nanograms RNA were used per RT-PCR using a one-step RT-PCR kit (Qiagen) with product-specific primers. To detect low abundance products, RNA was first reverse transcribed with a first-strand cDNA synthesis kit (Roche) using the random primers provided. One microgram RNA yielded $10 \mu \mathrm{l} \mathrm{cDNA}$, of which $1 \mu \mathrm{l}$ was used for each subsequent PCR with each primer pair.

\section{Real-time quantitative PCR}

Primers were chosen with the assistance of the computer application Primer 3.0 http://focker.wi.mit. edu/primer3/. We performed BLASTN searches against dbEST and non redundant sequence databases of GenBank to confirm the total gene specificity of the nucleotide sequences chosen as primers. Single product amplification was checked for each primer pair by analysis of product melt curves (ROTORGENE software Cambridge, UK).

All the PCRs were performed using a Corbett Research Rotorgene 2000 instrument. The thermal cycling conditions comprised an initial Taq heatactivation step at $95^{\circ} \mathrm{C}$ for $10 \mathrm{~min}$ and 45 cycles of $95^{\circ} \mathrm{C}$ for $15 \mathrm{~s}, 55^{\circ} \mathrm{C}$ for $30 \mathrm{~s}$ and $72{ }^{\circ} \mathrm{C}$ for $45 \mathrm{~s}$. Annealing temperature was dropped to $50^{\circ} \mathrm{C}$ for amplification of ChIP DNA. Specific PCR amplification products were detected by the fluorescent double-stranded DNA binding dye SYBR Green. Primer sequences used are available upon request. Experiments were performed at least three times with at least triplicates for each data point.

\section{ERE searching}

Human and mouse promoter sequences of $E_{2}$-regulated genes were obtained from EntrezGene (NCBI; www.ncbi.nlm.nih.gov), Promoser (Boston University) and UCSC genome browser; http://genome.ucsc.edu. A region $4 \mathrm{~kb}$ upstream and $1 \mathrm{~kb}$ downstream of the transcriptional start site (TSS) was selected and scanned for potential ERE using MatInspector (Genomatix; www.genomatix.de). The level of conservation of a $19 \mathrm{bp}$ sequence, containing the predicted ERE, was measured by using ClustalW (EBI; www.ebi.ac.uk) to align human and mouse orthologous promoters.

\section{Luciferase reporter assay}

ER transcriptional activity in PEO1 cells was measured using the Dual Luciferase Reporter Assay (Promega, UK) according to the manufacturer's protocol. The cells were co-transfected with luciferase reporter construct driven by either the consensus ERE from Xenopus vitellogenin A2 gene (GGTCA nnn TGACC) (Vit-ERE-tk-luc) (Klein-Hitpass et al. 1986) or the region $-1908 \mathrm{bp}$ to $+136 \mathrm{bp}$, relative to the transcriptional start site, from the rat fibronectin promoter (PGL2F1900) (Lee et al. 2000), and pRL-tk (renilla luciferase) to correct for transfection efficiency. Cells, starved of estrogen for $48 \mathrm{~h}$ in phenol red-free medium with $5 \%$ charcoal-stripped serum, were transfected using lipofectin reagent (Invitrogen, UK) according to the manufacturer's recommendations. Cells were treated with $1 \mathrm{nM} 17 \beta$-estradiol $24 \mathrm{~h}$ after transfection and luciferase activity was measured in lyzed cells $24 \mathrm{~h}$ later using a microplate luminometer (Berthold, Bad Wildbad, Germany).

\section{Chromatin immunoprecipitation}

Cells were grown to $95 \%$ confluence on $10-\mathrm{cm}$ dishes in phenol red-free RPMI 1640 supplemented with $5 \%$ double charcoal-stripped FCS for at least $48 \mathrm{~h}$. Following the addition of $17 \beta$-estradiol for various times, cells were washed twice with PBS and crosslinked with $1 \%$ formaldehyde at room temperature for $10 \mathrm{~min}$ followed by $5 \mathrm{~min}$ incubation with $0.125 \mathrm{M}$ glycine. Cells were then rinsed with ice-cold PBS and collected into PBS. Cells were washed sequentially with $1 \mathrm{ml}$ ice-cold PBS, buffer I $(0.25 \%$ Triton X-100, $10 \mathrm{mM}$ EDTA, $0.5 \mathrm{mM}$ EGTA, $10 \mathrm{mM}$ HEPES, 
pH 6.5) and buffer II ( $200 \mathrm{mM} \mathrm{NaCl}, 1 \mathrm{mM}$ EDTA, $0.5 \mathrm{mM}$ EGTA, $10 \mathrm{mM}$ HEPES, pH 6.5), then resuspended in $0.3 \mathrm{ml}$ lysis buffer $(1 \%$ SDS, $10 \mathrm{mM}$ EDTA, $50 \mathrm{mM}$ Tris- $\mathrm{HCl}$, pH 8.1$), 1 \times$ protease inhibitor cocktail (Roche) and sonicated three times for $10 \mathrm{~s}$ to give fragments in the range 0.8 to $2.5 \mathrm{~kb}$. For each immuno precipitate, $0.1 \mathrm{ml}$ lysate was diluted in dilution buffer ( $1 \%$ Triton X-100, 2 mM EDTA, $150 \mathrm{mM} \mathrm{NaCl}, 20 \mathrm{mM}$ Tris-HCl, $\mathrm{pH}$ 8.1) followed by immunoclearing with $2 \mu \mathrm{g}$ sonicated salmon sperm DNA and $20 \mu \mathrm{l}$ protein A-sepharose for $1 \mathrm{~h}$ at $4^{\circ} \mathrm{C}$. Immunoprecipitation was performed overnight at $4^{\circ} \mathrm{C}$ with specific antibodies to either ER $\alpha$ (Santa Cruz HC20) or acetylated histone H4 (Upstate \#06-866). After immunoprecipitation, $20 \mu \mathrm{l}$ protein A-Sepharose and $2 \mu \mathrm{g}$ salmon sperm DNA were added and the incubation was continued for another hour. Precipitates were washed sequentially for $15 \mathrm{~min}$ each in TSE I $(0.1 \%$ SDS, $1 \%$ Triton X-100, 2 mM EDTA, $20 \mathrm{mM}$ Tris-HCl, $\mathrm{pH} 8.1,150 \mathrm{mM} \mathrm{NaCl})$, TSE II $(0.1 \%$ SDS, $1 \%$ Triton X-100, $2 \mathrm{mM}$ EDTA, $20 \mathrm{mM}$ Tris- $\mathrm{HCl}$, $\mathrm{pH} 8.1,500 \mathrm{mM} \mathrm{NaCl})$, and buffer III $(0.25 \mathrm{M} \mathrm{LiCl}$, $1 \%$ NP-40, $1 \%$ deoxycholate, $1 \mathrm{mM}$ EDTA, $10 \mathrm{mM}$ Tris- $\mathrm{HCl}, \mathrm{pH} 8.1$ ). Precipitates were then washed three times with TE buffer (50 mM Tris- $\mathrm{HCl}, \mathrm{pH} 8.1 ; 1 \mathrm{mM}$ EDTA) and extracted twice with $1 \%$ SDS, $0.1 \mathrm{M}$ $\mathrm{NaHCO}_{3}$. Eluates were pooled and heated at $65^{\circ} \mathrm{C}$ for at least $6 \mathrm{~h}$ to reverse the formaldehyde cross-linking. DNA fragments were purified with a QIAquick Spin Kit (Qiagen, UK). For real-time PCR, $5 \mu 1$ from $50 \mu 1$ elution were used. IP was normalized to input DNA.

\section{Results}

\section{Expression of functional ER in human ovarian cancer cell lines}

To enable us to relate $E_{2}$-directed transcription to ER status and hormone responsiveness in ovarian cancer, we first assessed the expression of ER $\alpha$ and ER $\beta$ in 16 ovarian cancer cell lines. Western blotting with antibodies directed against either ER $\alpha$ or ER $\beta$ revealed that $\mathrm{ER} \alpha$ protein is expressed in PEO1, PEO1 ${ }^{\mathrm{CDDP}}$, PEO4, PEO6 and SKOV3 cells at levels similar to that observed in the ER $\alpha$-positive breast cell lines ZR-75-1 and MCF-7 (Fig. 1). ER $\beta$ was expressed to varying degrees in all cell lines tested.

\section{Estrogen-responsive cell lines with functional ER are growth responsive to estradiol}

Figure 2 shows $E_{2}$-induced changes in cell number relative to a control sample not exposed to $E_{2}$. Both

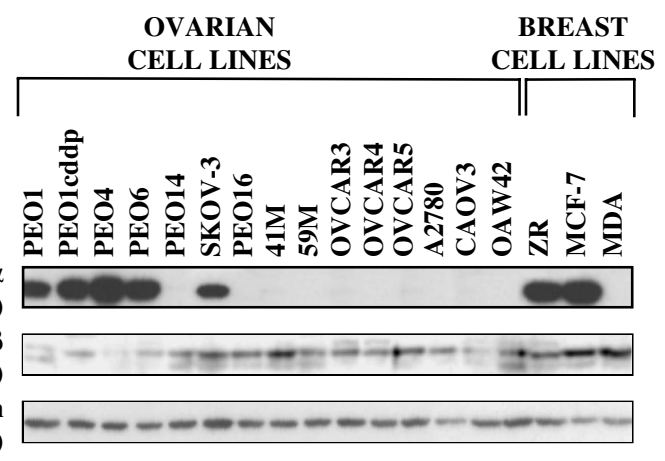

Figure 1 Expression of estrogen receptors in ovarian cancer cell lines. Western blot of ER $\alpha$ and $E R \beta$ protein expression in ovarian and breast cancer cell lines. Also shown are actin expression levels in each cell line to ensure equivalent total protein loading in each lane.

ER $\alpha$-positive PEO1 and PEO4 cell lines were growth stimulated by $E_{2}$ implying the presence of functional ER. SKOV-3 cells, despite expressing ER $\alpha$, did not show an increase in growth, relative to control, after treatment with $\mathrm{E}_{2}$. PEO14 cells, negative for $\mathrm{ER} \alpha$, also displayed a lack of growth-responsiveness to $E_{2}$. A further 9 ER $\alpha$-negative, ER $\beta$-positive ovarian cell lines (PEO16, 41M, 59M, OVCAR-3, OVCAR-4, OVCAR-5, A2780, CAOV3 and OAW42) were tested for growth sensitivity to $\mathrm{E}_{2}$ but did not respond despite expressing ER $\beta$. These data suggest that expression of $E R \alpha$ is necessary for $E_{2}$-induced growth and $E R \beta$ alone does not play a significant role in the growth response.

To further test which ER isoform mediates the growth response, PEO1, PEO4, PEO14 and SKOV3 cells were treated with either $E_{2}$, which activates both ER forms, or an agonist specific for either ER $\alpha$ (PPT) (Stauffer et al. 2000) or ER $\beta$ (DPN) (Meyers et al. 2001) (Fig. 2B). While PPT stimulated proliferation in a similar manner to $E_{2}$, DPN failed to induce a change in proliferation until concentrations reached $1 \mu \mathrm{M}$. At this high concentration, DPN has been shown to cross-activate ER $\alpha$ (Meyers et al. 2001). These results again indicate that growth response to estrogen in these cell lines is mediated by $\operatorname{ER} \alpha$ and not $\operatorname{ER} \beta$.

\section{$17 \beta$-Estradiol-mediated changes in gene expression}

To identify genes regulated by $\mathrm{E}_{2}$ in the PEO1 cell line, RNAs from untreated and $E_{2}$-treated cells were compared. RNAs from untreated cells and cells exposed to $10^{-10} \mathrm{M} \mathrm{E} \mathrm{E}_{2}$ for $24 \mathrm{~h}$ were isolated, labeled and hybridized to BD Atlas Cancer $1.2 \mathrm{~K}$ cDNA microarrays and 

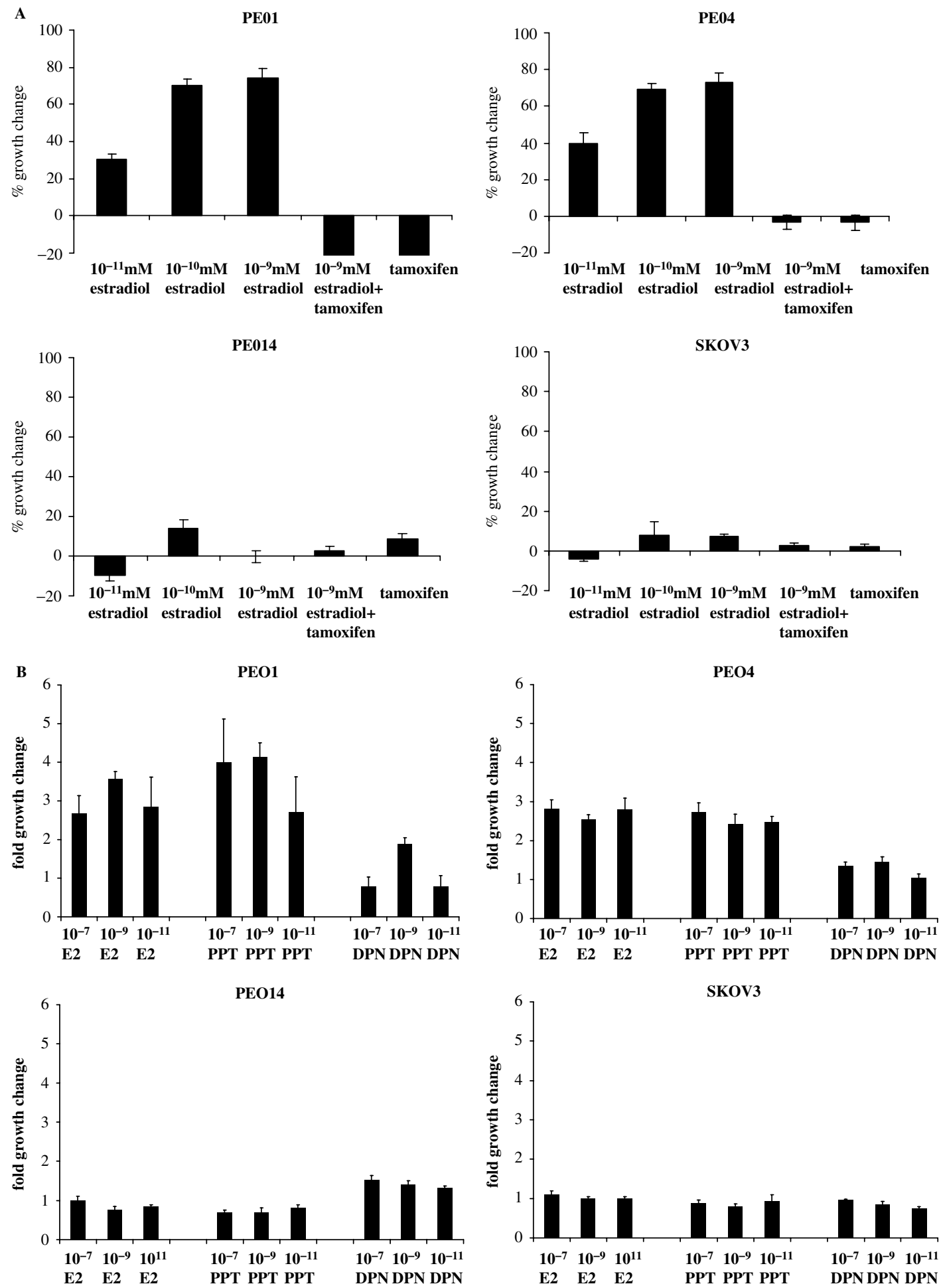

Figure 2 Effects of estrogens and anti-estrogens on ovarian cancer cell growth. (A, B) Results are shown as percentage change in cell number, compared with control cells incubated in estrogen-stripped media (see Materials and methods), after 5 days incubation with the indicated hormone. Tamoxifen was added at $1 \mu \mathrm{M}$. $\mathrm{E}_{2}$ and the specific ER $\alpha$ agonist PPT and ER $\beta$ agonist DPN were added at the concentrations indicated. 
$\mathbf{A}$

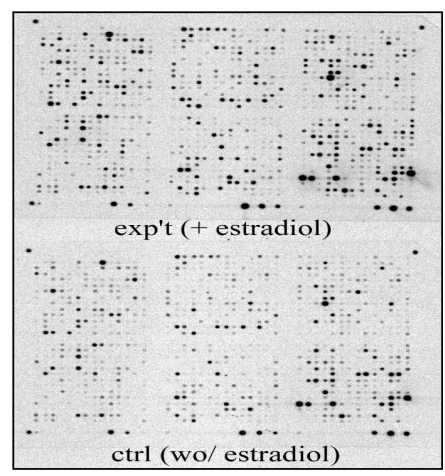

B

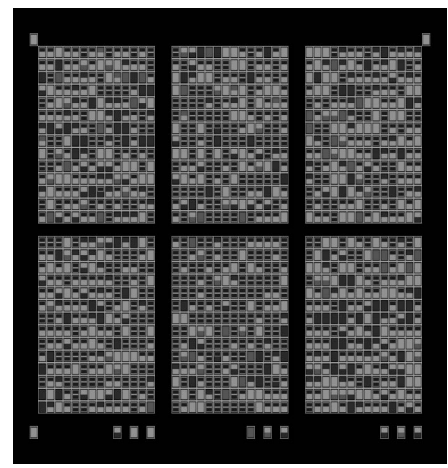

C

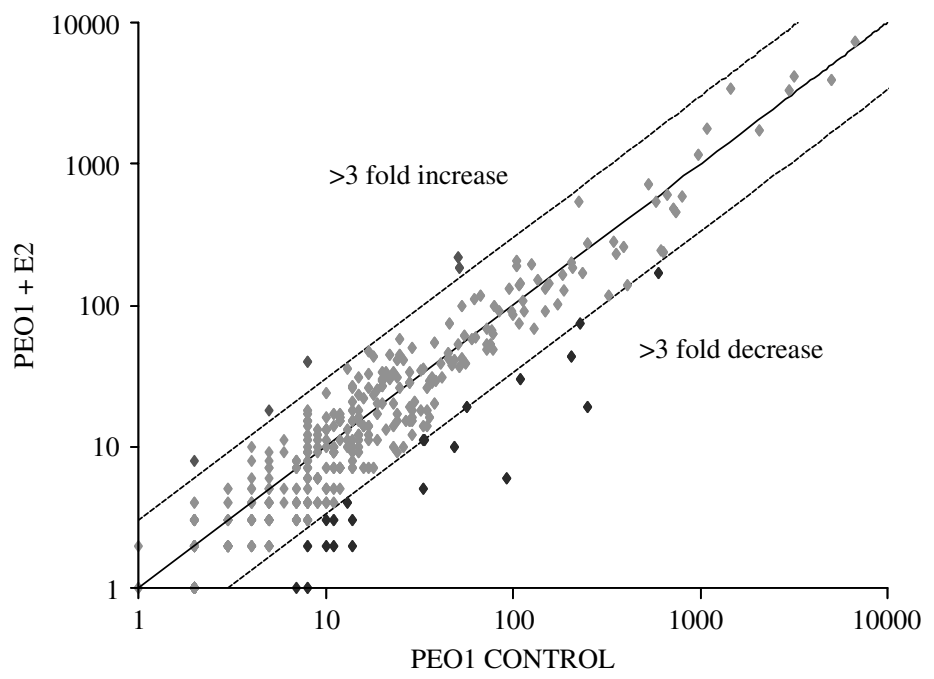

Figure 3 Estradiol-mediated changes in gene expression identified by cDNA microarray. (A) Gene expression profiles of PEO1 cells with and without $\mathrm{E}_{2}$-stimulation. ${ }^{33} \mathrm{P}$-Labeled $\mathrm{cDNA}$ from $\mathrm{E}_{2}$-stimulated and non-stimulated PEO1 cells was hybridized to microarrays and levels of expression were detected by phosphorimage analysis. (B) Atlaslmage software was used to generate a color schematic depicting changes in expression as determined by both the ratio of intensity values (upper half of boxes) and the difference in intensity values (lower half of boxes): up-regulated genes in red, down-regulated genes in blue and unchanged genes in green. (C) Bivariate comparison of gene expression fingerprints using $x, y$-scatterplot. Genes with equal expression values in both samples line up on the central identity line, whereas outliers correspond to up- or down-regulated genes. The two outer parallel lines represent threefold changes in expression level. Selected genes with expression changed by more than threefold were selected for verification by real-time quantitative PCR.

analyzed by phosphorimaging (Fig. 3A). BD AtlasImage software was used to generate a color schematic normalized comparison of the two arrays to demonstrate the extent of gene expression changes in PEO1 cells upon $\mathrm{E}_{2}$ stimulation (Fig. 3B). Figure 3C shows semi-quantitative similarities and differences between gene expression profiles of the two RNA populations. Each point in the scatterplot represents the expression values of a gene in two separate treatments, one value on the $\mathrm{X}$-axis (untreated control) and the other one on the $\mathrm{Y}$-axis $\left(\mathrm{E}_{2}\right.$-treated). The expression levels of the majority of genes were unaffected (lined up on the identity line); however, 5 genes were up-regulated and 23 genes were down-regulated by more than threefold in $E_{2}$-treated cells compared with untreated control cells (Table 1). Interestingly, genes up-regulated by $\mathrm{E}_{2}$, such as FOSL1, CTSD and TFAP4, are known to play a role in promoting cell proliferation. Of particular note, however, was the number of down-regulated genes, especially those involved in maintenance of the cytoskeleton, suggesting a role for $\mathrm{E}_{2}$ signaling in invasion and metastasis.

We next selected 16 genes showing changes greater than threefold over controls and verified these changes 
Table 1 cDNA expression array changes of modulated genes in PE01 cells after stimulation with $E_{2}$ and Putative Estrogen Response Elements in these estradiol-regulated genes

\begin{tabular}{|c|c|c|c|c|c|}
\hline Gene & Genbank & Fold-change & Putative ERE ${ }^{a}$ & $\begin{array}{l}\text { Position from } \\
\text { TSS }^{b} \text { (bp) }\end{array}$ & Conserved $^{\mathrm{C}}$ \\
\hline $\begin{array}{l}\text { TNFSF7 (CD27 ligand; } \\
\text { CD70 antigen) }\end{array}$ & L08096 & $3.6 \times$ up & tgaGGTCAtacTGgattag & -1488 to -1506 & - \\
\hline $\begin{array}{l}\text { TRAP1 (Tumor necrosis } \\
\text { factor type I receptor) }\end{array}$ & U12595 & $3.6 \times$ up $(3.0 \times)^{d}$ & gttGGTCAggcTGgtCttg & -2597 to -2615 & - \\
\hline FOSL1 (FRA1) & X16707 & $5.0 \times$ up $(6.4 \times)$ & tggGGTCAgacaGctCtgg & -1926 to -1944 & + \\
\hline $\begin{array}{l}\text { TFAP4 (AP4 DNA } \\
\text { binding protein) }\end{array}$ & S73885 & $4.0 \times$ up $(4.6 \times)$ & gttGGTCAggcTGgtCtcg & -1511 to -1529 & + \\
\hline CTSD (Cathepsin) & M11233 & $4.3 \times$ up $(4.1 \times)$ & cggGGTCAgcccGgCCcag & -125 to -143 & - \\
\hline CCNB1 (Cyclin B1) & M25753 & $4.0 \times$ down & ggcGGTCAgaaTGgtttct & -1908 to -1926 & - \\
\hline $\begin{array}{l}\text { UBL1 (Sentrin; SUMO1; } \\
\text { GAP modifying protein) }\end{array}$ & U83117 & $3.7 \times$ down & gccGGTCAgagcctgCttc & -912 to -930 & + \\
\hline CASP4 (Caspase 4) & U28014 & $8.0 \times$ down $(5.0)$ & gtaGGTCAtcaTGagtttg & -318 to -336 & $\mathrm{~N}$ \\
\hline $\mathrm{NOTCH} 4$ & U95299 & $3.1 \times$ down & taaGGTCAcaagtcCCtat & -3617 to -3635 & - \\
\hline IGFBP3 & M31159 & $15.3 \times$ down $(11.4 \times)$ & ccaGGTCAttactcCttca & -64 to -82 & - \\
\hline CDH6 (Cadherin 6) & D31784 & $5.0 \times$ down $(1.6 \times)$ & ataGGTCAatgTGcCagaa & -259 to -277 & + \\
\hline CYR61 & AF031385 & $5.0 \times$ down & cccGGTCAactcGcatcac & -507 to -535 & - \\
\hline KRT7 (keratin 7) & X03212 & $3.0 \times$ down $(2.5 \times)$ & acaGGTCAcccTGcaCcca & -3850 to -3868 & - \\
\hline FN1 (Fibronectin) & X02761 & $13.2 \times$ down $(9.5 \times)$ & gtgGGTCAcaaaGAttcct & -1687 to -1705 & + \\
\hline VIM (Vimentin) & X56134 & $3.0 \times$ down & ttcGGTCAcctTaACcttt & -1571 to -1589 & + \\
\hline KRT 13 (keratin 13) & X52426 & $3.7 \times$ down $(11.0 \times)$ & caaGGTCAccgTagCCctc & -379 to -397 & + \\
\hline TGFBI (BIGH3) & M77349 & $6.6 \times$ down $(5.0 \times)$ & aaagGTCAccaaaAaCatt & -3417 to -3399 & - \\
\hline DES (Desmin) & U59167 & $3.0 \times$ down & atgGGTCAgaaTttCcttt & -3446 to -3464 & - \\
\hline AKAP12 (Gravin) & M96322 & $7.0 \times$ down & none & & \\
\hline TRAM1 & X63679 & $7.0 \times$ down $(1.9 \times)$ & attGGTCAttgTttaCtgt & -3939 to -3957 & - \\
\hline $\begin{array}{l}\text { MMP } 11 \text { (Matrix } \\
\text { metalloproteinase 11) }\end{array}$ & X57766 & $4.7 \times$ down & aggGGTCAggagGtCCtct & -951 to -969 & - \\
\hline KRT4 (keratin 4) & X67683 & $4.7 \times$ down $(18.5 \times)$ & tcgGGTCAaaggGgCtctg & -2449 to -2467 & $\mathrm{~N}$ \\
\hline $\begin{array}{l}\text { PLAU (Urokinase-type } \\
\text { plasminogen activator) }\end{array}$ & M15476 & $7.0 \times$ down $(5.0 \times)$ & tctGGTCAcgtTtAtttac & -1847 to -1829 & + \\
\hline $\begin{array}{l}\text { MMP } 17 \text { (Matrix } \\
\text { metalloproteinase 17) }\end{array}$ & X89576 & $3.3 \times$ down & caaGGTCAtctgaAgCagg & -1123 to -1141 & - \\
\hline EIF2B1 & X95648 & $3.7 \times$ down & ggtGGTCAggggagCgtct & -245 to -263 & - \\
\hline LCN2 (Lipocalin 2) & X99133 & $3.5 \times$ down $(14.0 \times)$ & $\begin{array}{l}\text { tgaGGTCActgaGACCatc } \\
\text { gttGGTCAggcTGgCCttg }\end{array}$ & $\begin{array}{l}-789 \text { to }-807 \\
-1809 \text { to }-1827\end{array}$ & $\begin{array}{l}- \\
+\end{array}$ \\
\hline $\begin{array}{l}\text { GRSF1 (G-rich } \\
\text { sequence factor 1) }\end{array}$ & U07231 & $3.3 \times$ down & tgaGGTCAggcTGgttttt & -2275 to -2293 & - \\
\hline BENE & U017077 & $4.9 \times$ down $(3.5 \times)$ & $\begin{array}{l}\text { gggGGTCAaagattCCtta } \\
\text { gaaGGTggaaaTGgCtcag }\end{array}$ & $\begin{array}{l}-8 \text { to }+7 \\
-879 \text { to }-897\end{array}$ & $\begin{array}{l}- \\
+\end{array}$ \\
\hline
\end{tabular}

${ }^{a}$ Estrogen response elements obtained from MatInspector program; ${ }^{b}$ Position of ERE with respect to transcriptional start site; 'Sequence similarity score $>0.6$ for 19 base palindrome or 1.0 for half-site in ClustalW sequence alignment. ' $N$ ' = no mouse counterpart; ${ }^{\mathrm{d}} \mathrm{RT}$-PCR verified.

using real-time quantitative RT-PCR. All 16 genes, each analyzed in at least three independent experiments, consistently showed $\mathrm{E}_{2}$-induced expression changes in agreement with the microarray analysis results in Table 1.

\section{$17 \beta$-Estradiol-mediated changes correlate with ER $\alpha$ expression and growth responsiveness}

The expression of a randomly selected subset of genes, identified as $\mathrm{E}_{2}$ regulated in the PEO1 cell line, was assessed in the growth-responsive cell line PEO4 and the non-growth-responsive SKOV3 and PEO14 cell lines. Figure 4 shows that $\mathrm{E}_{2}$ also induced a change in expression of these genes in PEO4 cells, whereas PEO14 and SKOV3 cells were non-responsive. This implies that the expression of functional ER is necessary to mediate $E_{2}$ regulation of these genes.

To establish whether the gene expression changes induced by $E_{2}$ were ER mediated, we tested the ability of the anti-estrogen 4-hydroxy-tamoxifen (OHT) to negate the observed estrogenic effect. This compound has been shown to bind specifically to the 

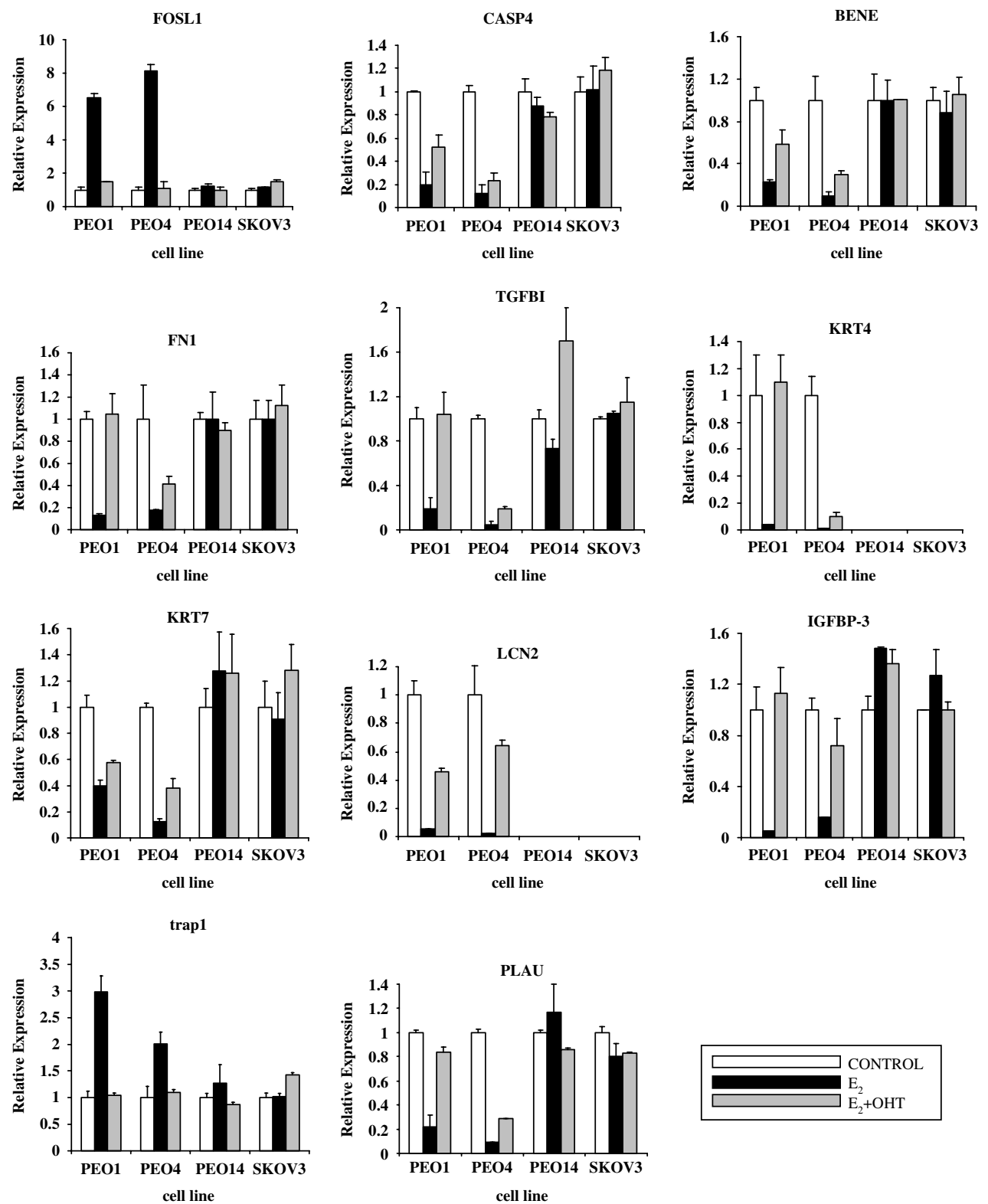

Figure 4 Estradiol-induced changes in gene expression in ovarian cancer cell lines correlate with ER status and estrogen responsiveness. These are abrogated by tamoxifen (OHT). Graphs show fold change in gene expression, compared with control, after incubation with $1 \mathrm{nM} \mathrm{E}_{2}$ for $48 \mathrm{~h}$, to confirm the trend observed with microarray analysis. Quantitation of mRNA expression was carried out by real-time RT-PCR normalized to $18 \mathrm{~s}$ rRNA levels.

ER, causing it to undergo a conformational change and thus rendering it unable to bind $\mathrm{E}_{2}$. Cells were treated with $\mathrm{E}_{2}$ or anti-estrogen, either alone or in combination, over a $48 \mathrm{~h}$ period. Figure 4 shows that OHT effectively blocked the ability of $\mathrm{E}_{2}$ to mediate gene expression changes in the PEO1 and PEO4 cell lines.
Assaying gene expression levels in PEO1 and PEO4 cells treated with ER $\alpha$ and ER $\beta$ agonists demonstrated that activation of $\mathrm{ER} \alpha$ alone is sufficient to cause the effects observed with $\mathrm{E}_{2}$ treatment for all of the 8 genes tested (Fig. 5). DPN was unable to induce gene expression changes even at concentrations up to $1 \mu \mathrm{M}$ (data not shown). This suggests that $\mathrm{E}_{2}$-mediated 
TRAP1

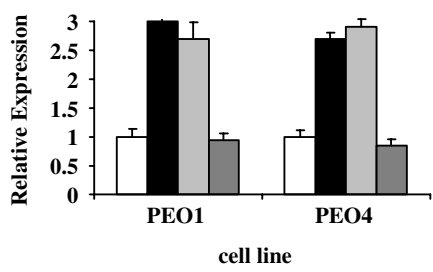

IGFBP3

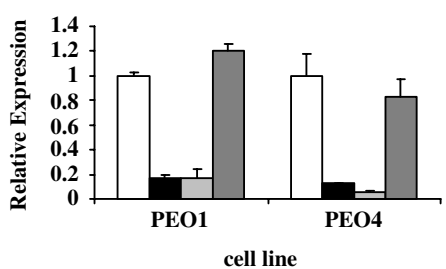

PLAU

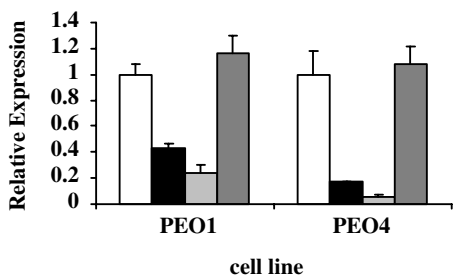

FOSL1

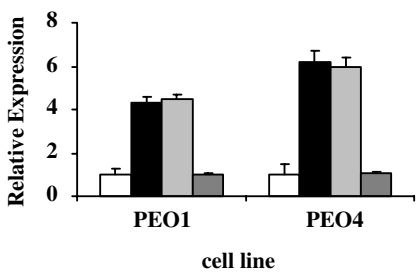

BENE

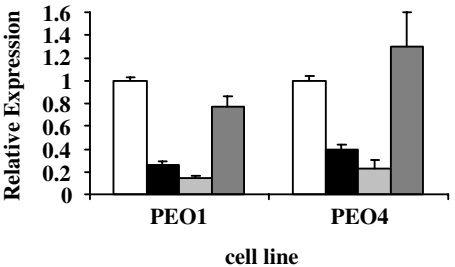

TGFBI

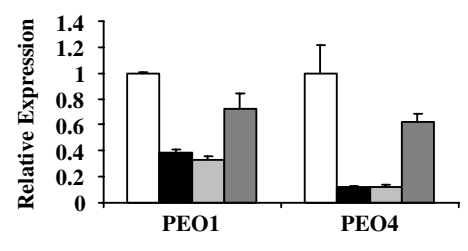

cell line
LCN2

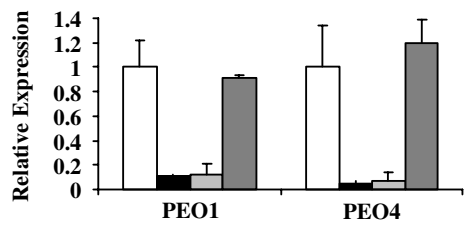

cell line

FN1
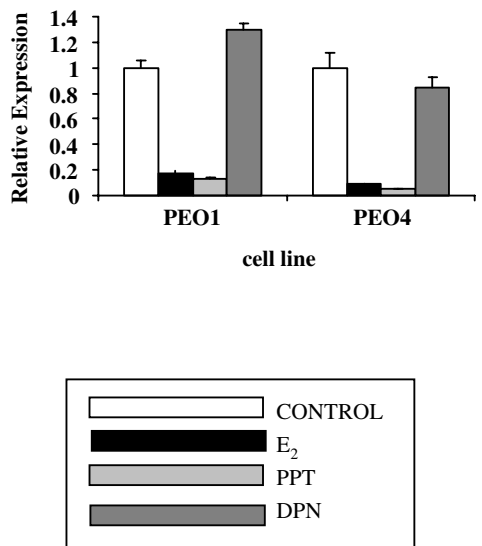

Figure 5 Effects of the ER $\alpha$ and ER $\beta$ specific agonists, PPT and DPN respectively, on gene expression in the PEO1 and PEO4 ovarian cancer cell lines. Quantitation of mRNA expression was carried out by real-time RT-PCR normalized to 18 s rRNA levels.

gene expression changes are mediated by activation of $E R \alpha$ and not the consequence of activation of ER $\beta$.

\section{Effects of $17 \beta$-estradiol on mRNA stability}

To establish whether changes in transcript levels of $\mathrm{E}_{2}$-modulated genes were due to a change in transcription rate or a change in mRNA stability, the rate of decay of each transcript, in actinomycin D-treated (to block further RNA synthesis) PEO1 cells preincubated with $1 \mathrm{nM} \mathrm{E} \mathrm{E}_{2}$ for $48 \mathrm{~h}$, was measured and compared with an untreated control. RT-PCR was then used to measure the levels of target mRNA at various time points after actinomycin $\mathrm{D}$ treatment. Figure 6A demonstrates that up-regulation of expression of FOSL1 and TRAP1 genes was not a result of $E_{2}$-mediated stabilization of mRNA. Interestingly, down-regulated mRNA transcripts IGFBP3, BENE, $F N 1, P L A U$ and TGFBI were stabilized in the presence of $\mathrm{E}_{2}$ (estradiol-reduced expression levels of LCN2 were too low to accurately measure decay rate). These results are consistent with the observed changes in
mRNA expression being due to $\mathrm{E}_{2}$-regulated transcription rate changes and not due to effects on mRNA stability.

\section{ER primary target genes identified in the presence of cycloheximide}

It is likely that some of these genes may be regulated because of secondary effects induced by the primary targets of ER. To identify primary targets, we analyzed the effect of $E_{2}$ in the absence and presence of cycloheximide (CHX). The inhibition of protein synthesis by $\mathrm{CHX}$ prevents most of the secondary gene regulation that is not transactivated directly by ER. ER protein levels remained relatively stable in the presence of $\mathrm{CHX}$ throughout the experiment. PEO1 cells were pretreated with $\mathrm{CHX}$ for $10 \mathrm{~min}$ prior to $\mathrm{E}_{2}$ stimulation for a further $24 \mathrm{~h}$. Six out of the subset of eight gene products tested were shown to be direct targets of $E_{2}: E_{2}$ induced a change in mRNA expression level in the presence of $\mathrm{CHX}$ (Fig. 6B). Preventing de novo protein synthesis greatly reduced the effects of $E_{2}$ 

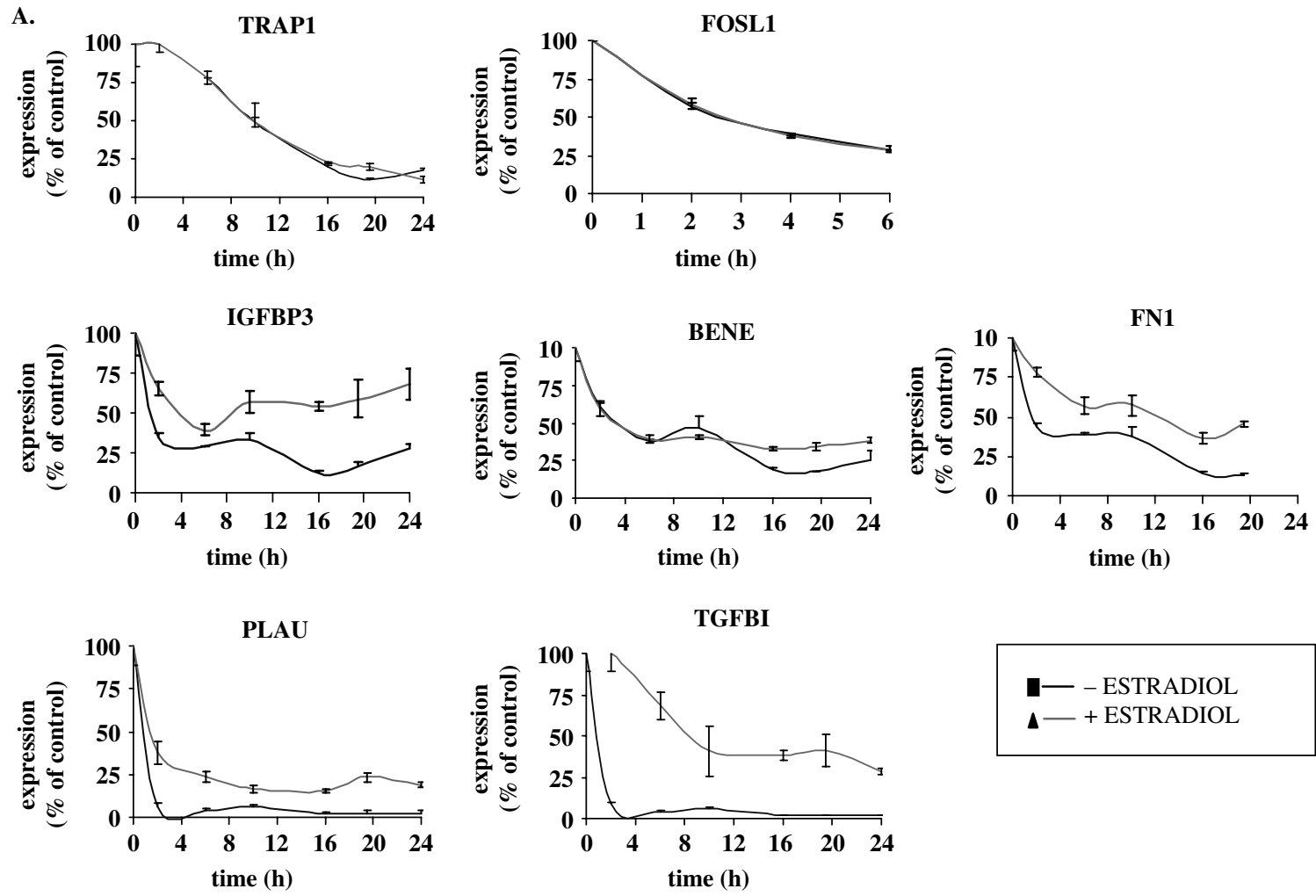

B.
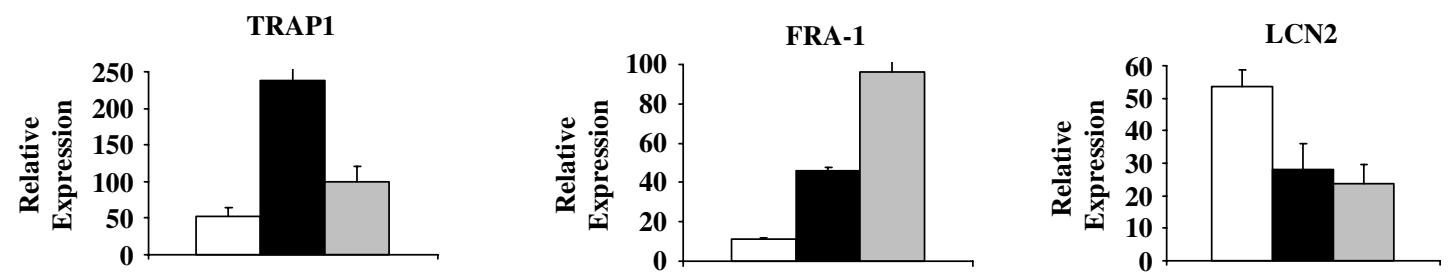

IGFBP3
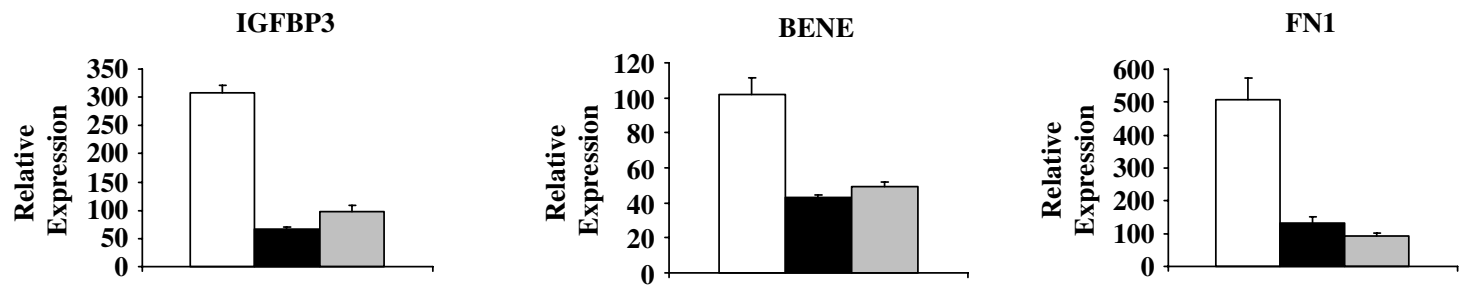

PLAU
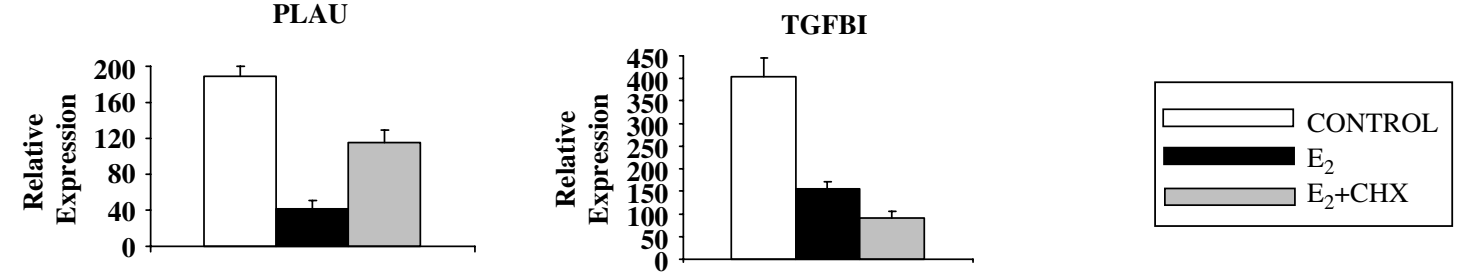
on the expression of PLAU and TRAPI suggesting that these genes are, at least partly, regulated by transcriptional targets of ER.

\section{Estrogen response elements in regulated genes}

The promoters of some genes in this study have previously been shown to have estrogen-responsive elements, which bind estrogen receptor (e.g. CTSD). To investigate whether the novel estrogen-regulated genes identified in this study contain potential binding sites for ER, we performed a computer-assisted analysis of the $5^{\prime}$-flanking sequence of each gene. Using MatInspector professional software (www.genomatrix. gsf.de), we examined whether ER consensus sites were contained within the promoter region or the first intron of the 28 estradiol-responsive genes. To improve specificity, we used threshold values of 1.0 for core similarity and 0.85 for matrix similarity. Altogether 27 of the 28 genes investigated demonstrated at least a half-palindromic sequence GGTCA within $4 \mathrm{~kb}$ of the transcription start site (TSS) (Table 1). Based on the hypothesis that functionally important non-coding genomic sequences will be conserved during evolution, murine orthologous counterparts for each promoter were retrieved from the UCSC genome browser and sequences aligned using ClustalW. Comparative genomic analysis showed that 10 out of 25 promoters tested contained a conserved ERE sequence (sequence similarity score across $19 \mathrm{bp}$ sequence $>0.6$, or complete conservation of half-site ERE). The genes CASP4 and KRT4 do not have mouse orthologs.

\section{$E_{2}$-mediated down-regulation of FN1 in ovarian cancer cells involves recruitment of ER and histone deacetylase activity to the FN1 promoter}

Of particular interest was the number of downregulated genes identified as ER targets. FN1, although previously identified as being up-regulated in response to estradiol in cardiac fibroblasts (Mercier et al. 2002) and during mouse mammary gland development (Woodward et al. 2001), was one gene that was strikingly down-regulated in ER $\alpha$-positive ovarian cancer cells. Figure 7A shows the location of a highly conserved putative estrogen response element in human, mouse and rat genomes. In accordance with the mRNA changes observed in response to estradiol, protein levels of $\mathrm{FN} 1$ are also greatly reduced in the presence of $E_{2}$. Interestingly, full serum, not double charcoal stripped, possesses enough hormonal activity to reduce expression of FN1 protein. Only stripped FCS allows full de-repression of FN1 expression. Induction of $\mathrm{E}_{2}$-responsive progesterone receptor protein is also shown together with expression of beta-actin as a loading control. To assess whether $\mathrm{E}_{2}$ causes transcriptional repression at the FN1 promoter, we transfected ovarian PEO1 cells with a luciferase reporter construct of the $F N 1$ promoter region -1908 to +136 and measured luciferase activity after treatment with $E_{2}$ and compared the results with that of vit-ERE-luc, which is known to be induced by $E_{2}$. Results show that, as expected, $E_{2}$ induced expression of luciferase through the vit ERE in ovarian cancer cells. However, the activity of the FN1 promoter was greatly reduced by the addition of $E_{2}$. These results are in agreement with the idea that $E_{2}$ causes down-regulation of $F N 1$ through an ERE in the promoter region. Down-regulation of the FN1 promoter is shown in Fig. 7D to be sensitive to the histone deacetylase inhibitor trichostatin A (TSA) as FN1 promoter driven luciferase activity and endogenous FN1 mRNA and protein levels are restored when TSA is added to $\mathrm{E}_{2}$-treated cells. This suggests that down-regulation of FN1 occurs through recruitment of histone deacetylase activity to the promoter region. To demonstrate that $\mathrm{E}_{2}$ recruits $\mathrm{ER} \alpha$ to the promoter of $F N 1$, chromatin immunoprecipitation was used. Figure 7E shows that upon $\mathrm{E}_{2}$ stimulation, $\mathrm{ER} \alpha$ is recruited to the endogenous FN1 promoter with a concurrent decrease in the level of acetylated histone H4. Together, these results present a suggestion that $\mathrm{E}_{2}$ treatment causes recruitment of a transcriptional repression complex of ER $\alpha$ and histone deacetylases to the $F N 1$ promoter causing a reduction in FN1 mRNA and protein levels.

\section{Discussion}

The results obtained in this study indicate that $\mathrm{ER} \alpha$ mediates both the growth response and gene

Figure 6 (A) Effects of estradiol on the stability of a subset of estrogen target mRNAs. Graphs show normalized gene expression levels in PEO1 cells after incubation with actinomycin D for various times. Quantitation of mRNA expression was carried out by real-time RT-PCR. (B) Effects of cycloheximide ( $\mathrm{CHX}$ ) on $\mathrm{E}_{2}$-induced gene expression changes. Graphs show relative gene expression levels after incubation with the treatments indicated. 
A

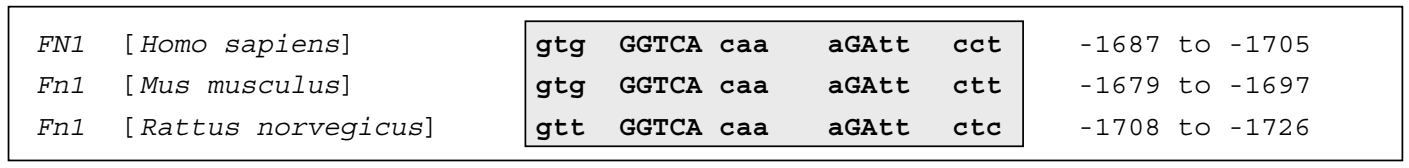

B

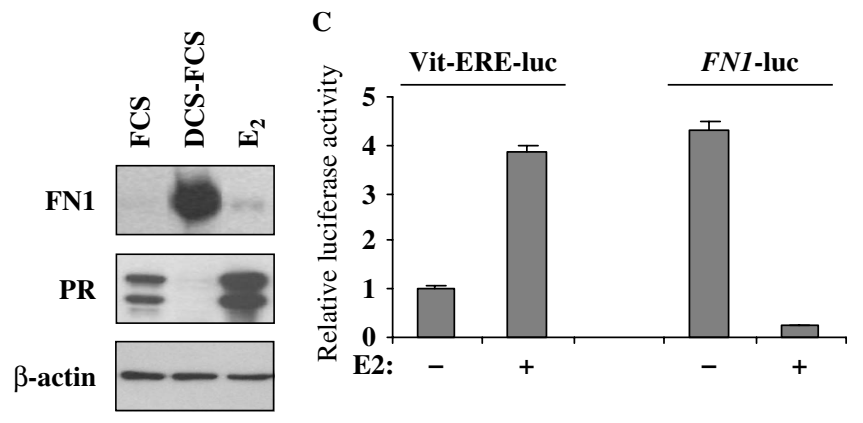

D
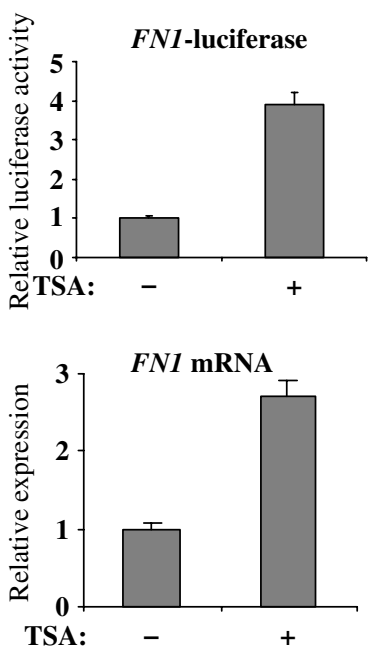

Anti-FN1

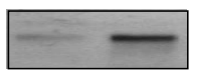

Anti-actin

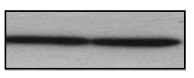

TSA: $\quad-\quad+$

$\mathbf{E}$

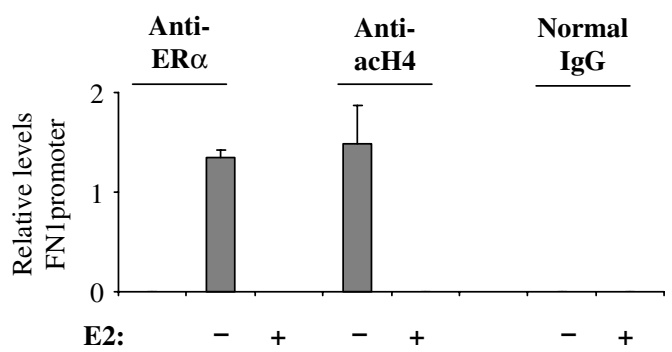

Figure 7 (A) Sequence alignment of the putative ERE in the FN1 gene. Shown are the alignments of human, mouse and rat sequences. Identity to the vit consensus ERE sequence is shown by capitalization. Location of ERE is shown relative to the transcriptional start site. (B) Western blot analysis of FN1 and progesterone receptor protein expression changes in response to $\mathrm{E}_{2}$. Beta-actin expression is included as a loading control. All cells were incubated for $48 \mathrm{~h}$ in DCS-FCS prior to treatment with $1 \mathrm{nM} \mathrm{E}_{2}$, $10 \%$ FCS or $5 \%$ DCS-FCS, as indicated, for $96 \mathrm{~h}$. (C) Transfection of PEO1 cells with either a vitellogenin-ERE luciferase reporter or an FN1 promoter $(-1908$ to $+136 \mathrm{bp})$ luciferase reporter. Cells were treated either with vehicle or $1 \mathrm{nM} \mathrm{E}_{2}$, as indicated, for $24 \mathrm{~h}$. Relative changes in reporter activity in response to $E_{2}$ are shown. (D) De-repression of FN1 by trichostatin A (TSA). Upper panel: FN1-luciferase reporter transfected PEO1 cells; middle panel: quantitative RT-PCR measurement of relative levels of endogenous FN1 mRNA; bottom panel: Western blot analysis of endogenous FN1 protein levels, actin expression is also shown for normalization. (E) Quantitative PCR showing results of chromatin immunoprecipitation of the FN1 promoter via antibodies to $\mathrm{ER} \alpha$, acetylated histone $\mathrm{H} 4(\mathrm{acH} 4)$ or normal IgG in the presence of either vehicle $(-)$ or $10 \mathrm{nM} \mathrm{E}_{2}(+)$ for $1 \mathrm{~h}$. 
expression changes in ovarian cancer cells exposed to $E_{2}$. Ovarian cancer cell lines expressing only ER $\beta$ are growth unresponsive to $E_{2}$. Expression levels of ER $\beta$ are high in the normal ovary and, in a number of studies, this isoform predominates over $\mathrm{ER} \alpha$ not only in the normal ovary but also in benign ovarian tumors (Brandenberger et al. 1997, Enmark et al. 1997, Kuiper et al. 1997, Pujol et al. 1998). ERß appears protective, as adenoviral delivery of this gene into ovarian cancer cells has been shown to inhibit cell proliferation and motility and enhance apoptosis (Bardin et al. 2004). Progression to ovarian cancer leads to a change in the ratio of $E R \alpha$ to $E R \beta$, with levels of ER $\alpha$ being generally higher than ER $\beta$ (Brandenberger et al. 1997, Enmark et al. 1997, Kuiper et al. 1997, Pujol et al. 1998, Rutherford et al. 2000, Bardin et al. 2004, Lindgren et al. 2004), further suggesting that either ER $\beta$ confers a protective effect and/or ER $\alpha$ promotes growth and invasion. This is further supported by a study comparing metastatic ovarian cancer with primary ovarian cancers wherein only $\mathrm{ER} \alpha$ was found in metastatic disease with $\mathrm{ER} \beta$ being no longer present (Rutherford et al. 2000). These data are all consistent with the idea that different ER isoforms are performing distinct roles in the ovary - ER $\alpha$ function being associated with malignant growth and progression, whilst ER $\beta$ plays a protective role.

We are not aware of any ER $\alpha$-negative ovarian cancer cell lines that respond to estrogen and these data are in line with previous reports that the presence of this receptor at moderate to high levels is essential for a growth function. A recent clinical trial, investigating the effectiveness of the aromatase inhibitor letrozole in ovarian cancer treatment, showed a clear association between response and higher levels of expression of $\mathrm{ER} \alpha$ (Bowman et al. 2002). However, in that trial, as in the current study with SKOV-3, it is apparent that not all $\mathrm{ER} \alpha$-positive cells respond to $E_{2}$. This may be due to disabling mutations of the ER, or the absence of critical cofactors (coactivators), or the presence of repressors, which will markedly influence the transcriptional (and growth) response (Shang et al. 2000). Alternatively, other growth regulatory pathways, such as the erbB2 receptor signaling pathways, may be up-regulated, essentially bypassing estrogen's control (Dowsett 2001). This may explain the lack of $\mathrm{E}_{2}$ response in the SKOV-3 cell line, as it markedly overexpresses erbB2 (Hua et al. 1995).

Since the functionality of ER $\alpha$ will be exhibited as changes in transcription of regulated genes, gene changes were sought by use of microarray technology after $E_{2}$ exposure. A limited number of genes have already been identified as being estrogen regulated in ovarian cancer. These include genes linked to proliferation (c-myc (Chien et al. 1994, Hua et al. 1995) and insulin-like growth factor binding proteins (IGFBPs) (Krywicki et al. 1993)), differentiation (progesterone receptor (Nash et al. 1989, Langdon et al. 1994b)) and to invasion (CTSD (Galtier-Dereure et al. 1992, Rowlands et al. 1993) and fibulin-1 (Clinton et al. 1996, Moll et al. 2002)). Two of these genes, namely IGFPB3 and CTSD, were present on the microarray and shown to be modulated by $E_{2}$. In the present study we identified regulators of the cell cycle (CCNB1), apoptosis (TNFSF7, TRAP1, UBL1 and CASP4), transcription (FOSL1, TFAP4, EIF2BI) and signaling (NOTCH4, IGFPB3, BENE, $L C N 2, G R S F 1$ ). Many of these modulated genes are also linked to either the cytoskeleton and extracellular matrix (CTSD, CDH6, CYR61, KRTS 4,7 and 13, VIM, TGFBI, DES, AKAP12, TRAM1, MMPS 11 and 17, PLAU) and hence could be involved in tumor spread and metastasis. Other than CTSD and IGFBP3, we are only aware that $C C N B 1$ (Zoubine et al. 1999), CYR61 (Tsai et al. 2002), FN1 (Woodward et al. 2001), PLAU (Levenson et al. 1998) and LCN2 (Seth et al. 2002) have been reported as being modulated by $E_{2}$. To confirm that these changes were mediated via ER, reversals by the ER competitor OHT were demonstrated. Similarly, these gene expression changes were not seen in the ER $\alpha$-negative PEO14 cell line. Use of the $E R \alpha$ and $E R \beta$ specific agonists indicated that the $\mathrm{E}_{2}$-modulated changes in expression could be reproduced by the ER $\alpha$ agonist (PPT) while the ER $\beta$ specific agonist (DPN) had no effect. As for the growth changes, these data support the importance of ER $\alpha$ over ER $\beta$ in this disease. A recent report exploring tissue-specific responsiveness to estrogen concluded that $\mathrm{ER} \alpha$ mediated estrogen regulation even in tissues possessing high levels of ER $\beta$ expression (Jelinsky et al. 2003) and our results in malignant tissue are in line with this.

Of the 8 genes studied as being either direct or indirect targets of $E_{2}, 6$ demonstrated equivalent expression changes in the presence of $\mathrm{CHX}$, indicating no requirement for new protein synthesis, thereby implicating a direct action of $E_{2}$ on these target genes. For TRAP1 and PLAU, there was some inhibition of the expression changes in the presence of $\mathrm{CHX}$ suggesting that expression of these genes is at least partially regulated by downstream effectors involving new protein synthesis.

The presence of an estrogen receptor binding site was sought in the promoter regions of the target genes 
identified, and all but one of these genes possessed at least a half-palindromic sequence GGTCA in the $4 \mathrm{~kb}$ region prior to the transcriptional start site, with most within a $2 \mathrm{~kb}$ region. Previous reports have shown that such incomplete motifs might transduce ER signaling (Tora et al. 1988). Indeed, very few estrogen-regulated genes contain the consensus ERE palindromic sequence (GGTCAnnnTGACC) and there is abundant evidence that half-ERE sites mediate many of estrogen's actions through co-operation with other binding sites e.g. Sp1 (reviewed in Klinge 2001, O'Lone et al. 2004). The use of actinomycin D suggested that the observed changes in mRNA expression were due to $\mathrm{E}_{2}$-regulated transcription rate changes and not due to effects on mRNA stability, as the up-regulated genes (FOSLI and TRAPI) were not stabilized in the presence of both $\mathrm{E}_{2}$ and actinomycin $\mathrm{D}$ and the down-regulated genes showed higher rather than lower transcript levels in the presence of both $\mathrm{E}_{2}$ and actinomycin $\mathrm{D}$.

Several genes, identified as being $\mathrm{E}_{2}$-regulated in ovarian cancer cells, have previously been shown to be $E_{2}$ targets in other tissue types. However, the effects of $E_{2}$ observed in previous studies opposed the effects observed in this study. For example, Cyr61, identified here as a down-regulated $\mathrm{E}_{2}$ target, has previously been shown to be induced by $\mathrm{E}_{2}$ in the mammary adenocarcinoma cell line MCF-7 (Sampath et al. 2001). PLAU, also down-regulated by $\mathrm{E}_{2}$ in this study, has been shown to be up-regulated by $\mathrm{E}_{2}$ during fracture healing (Hatano et al. 2004), and is also upregulated in response to $E_{2}$ in several breast cell lines (Seth et al. 2002). FN1, which was down-regulated in our study yet up-regulated in other cell types (Woodward et al. 2001, Mercier et al. 2002), was investigated further. We have shown that in ovarian cancer cells the promoter region of the $F N 1$ gene is responsive to $\mathrm{E}_{2}$, and that as well as recruiting ER $\alpha$ to the promoter, a TSA-sensitive histone deacetylase activity is also recruited. Reduction in acetylation of histone $\mathrm{H} 4$ is known to be associated with transcriptional repression, providing a plausible mechanism for E2-mediated down-regulation of this gene.

In conclusion, these results strongly support a role for $E R \alpha$ but not $E R \beta$ in the growth regulation of ovarian cancer and are consistent with the observed enhanced ratio of ER $\alpha$ over ER $\beta$ observed in ovarian cancers. We have identified a number of novel estrogen-regulated genes and have shown that some previously identified targets of $\mathrm{E}_{2}$ respond differently to $E_{2}$ in ovarian cancer cells. These targets will be further explored as potential mediators of estrogen's action in this particular disease.

\section{Acknowledgement}

The authors declare that there is no conflict of interest that would prejudice the impartiality of this scientific work.

\section{References}

Ahlgren JD, Ellison NM, Gottlieb RJ, Laluna F, Lokich JL, Sinclair PR, Ueno W, Wampler GL, Yeung K, Alt D \& Fryer JG 1993 Hormonal palliation of chemoresistant ovarian cancer: three consecutive Phase II trials of the Mid-Atlantic Oncology Program. Journal of Clinical Oncology 10 1957-1968.

Bardin A, Hoffmann P, Boulle N, Katsaros D, Vignon F, Pujol P \& Lazennec G 2004 Involvement of estrogen receptor $\beta$ in ovarian carcinogenesis. Cancer Research 64 5861-5869.

Boente MP, Hurteau J, Rodriguez GC, Bast RC Jr \& Berchuck A 1993 The biology of ovarian cancer. Current Opinion in Oncology 5 900-907.

Bowman A, Gabra H, Langdon SP, Lessells A, Stewart M, Young A \& Smyth JF 2002 CA125 response is associated with estrogen receptor expression in a phase II trial of letrozole in ovarian cancer: identification of an endocrine-sensitive subgroup. Clinical Cancer Research 8 2233-2239.

Brandenberger AW, Tee MK, Lee JY, Chao V \& Jaffe RB 1997 Tissue distribution of estrogen receptors alpha (ER-alpha) and beta (ER-beta) mRNA in the midgestational human fetus. Journal of Clinical Endocrinology and Metabolism 82 3509-3512.

Chien C-H, Wang F-F \& Hamilton TC 1994 Transcriptional activation of c-myc proto-oncogene by estrogen in human ovarian cancer cells. Molecular and Cellular Endocrinology 99 11-19.

Clinton GM, Rougeot C, Derancourt J, Roger P, Defrenne A, Godyna S, Argraves WS \& Rochefort H 1996 Estrogens increase the expression of fibulin-1, an extracellular matrix protein secreted by human ovarian cancer cells. PNAS 93 316-320.

Dowsett M 2001 Overexpression of HER-2 as a resistance mechanism to hormonal therapy for breast cancer. Endocrine-Related Cancer 8 191-195.

Enmark E, Pelto-Huikko M, Grandien K, Lagercrantz S, Lagercrantz J, Fried G, Nordenskjold M \& Gustafsson JA 1997 Human estrogen receptor beta-gene structure, chromosomal localization, and expression pattern. Journal of Clinical Endocrinologyand Metabolism 82 4258-4265.

Evans RM 1988 The steroid and thyroid hormone receptor superfamily. Science $\mathbf{2 4 0} 889-895$.

Galtier-Dereure F, Capony F, Maudelonde T \& Rochefort H 1992 Estradiol stimulates cell growth and secretion of procathepsin D and a 120-kilodalton protein in the human ovarian cancer cell line BG-1. Journal of Clinical Endocrinology and Metabolism 75 1497-1502. 
Green S \& Chambon P 1988 Nuclear receptors enhance our understanding of transcription regulation. Trends in Genetics 4 309-314.

Green S, Walter P, Kumar V, Krust A, Bornert JM, Argos P \& Chambon P 1986 Human oestrogen receptor cDNA: sequence, expression and homology to v-erbB-A. Nature 320 134-139.

Greene GL, Gilna P, Waterfield M, Baker A, Hort Y \& Shine J 1985 Sequence and expression of human estrogen receptor complementary DNA. Science 231 1150-1154.

Greenlee RT, Murray T, Bolden S \& Wingo PA 2000 Cancer statistics, 2000. CA: A Cancer Journal for Clinicians 50 7-33.

Hatano H, Siegel HJ, Yamagiwa H, Bronk JT, Turner RT, Bolander ME \& Sarkar G 2004 Identification of estrogenregulated genes during fracture healing using DNA microarray. Journal of Bone and Mineral Metabolism 22 224-235.

Hatch KD, Beecham JB, Blessing JA \& Creasman WT 1991 Responsiveness of patients with relapsed ovarian cancer to tamoxifen. Cancer 68 269-271.

Hua W, Christianson T, Rougeot C, Rochefort H \& Clinton GM 1995 SKOV-3 ovarian carcinoma cells have functional estrogen receptor but are growth resistant to estrogen and anti-estrogens. Journal of Steroid Biochemistry and Molecular Biology 55 279-285.

Jelinsky SA, Harris HA, Brown EL, Flanagan K, Zang X, Tunkey C, Lai K, Lane MV, Simcoe DK \& Evans MJ 2003 Global transcription profiling of estrogen activity: estrogen receptor- $\alpha$ regulates gene expression in the kidney. Endocrinology 144 701-710.

Klein-Hitpass L, Schorpp M, Wagner U \& Ryffel GU 1986 An estrogen-responsive element derived from the $5^{\prime}$ flanking region of the Xenopus vitellogenin A2 gene functions in transfected human cells. Cell 46 1053-1061.

Klinge CM 2001 Estrogen receptor interaction with estrogen response elements. Nucleic Acids Research 29 2905-2919.

Krywicki RF, Figueroa JA, Jackson JG, Kozelsky TW, Shimasaki S, Von Hoff DD \& Yee D 1993 Regulation of insulin-like growth factor binding proteins in ovarian cancer cells by oestrogen. European Journal of Cancer 29A 2015-2019.

Kuiper GG, Carlsson B, Grandien K, Enmark E, Haggblad J, Nilsson S \& Gustafsson JA 1997 Comparison of the ligand binding specificity and transcript tissue distribution of estrogen receptors alpha and beta. Endocrinology 138 863-870.

Lacey Jr JV, Mink PJ, Lubin JH, Sherman ME, Troisi R, Hartge P, Schatzkin A \& Schairer C 2002 Menopausal hormone replacement therapy and risk of ovarian cancer. Journal of the American Medical Association 288 334-341.

Langdon SP, Lawrie SS, Hay FG, Hawkes MM, McDonald A, Hayward IP, Schol DJ, Hilhers J, Leonard RCF \& Smyth JF 1988 Characterization and properties of nine human ovarian adenocarcinoma cell lines. Cancer Research 48 6166-6172.
Langdon SP, Hawkes MM, Lawrie SS, Hawkins RA, Resdale AL, Crew AJ, Miller WR \& Smyth JF 1990 Oestrogen receptor expression and the effects of oestrogen and tamoxifen on the growth of human ovarian carcinoma cell lines. British Journal of Cancer 62 213-216.

Langdon SP, Crew AJ, Ritchie AA, Muir M, Wakeling A, Smyth JF \& Miller WR $1994 a$ Growth inhibition of oestrogen receptor-positive human ovarian carcinoma by anti-oestrogens in vitro and in a xenograft model. European Journal of Cancer 30A 682-686.

Langdon SP, Hirst GL, Miller EP, Hawkins RA, Tesdale AL, Smyth JF \& Miller WR $1994 b$ The regulation of growth and protein expression by estrogen in vitro: a study of 8 human ovarian carcinoma cell lines. Journal of Steroid Biochemistry and Molecular Biology $\mathbf{5 0}$ 131-135.

Lee B-H, Kim M-S, Rhew J-H, Park R, Crombrugghe B \& Kim IS 2000 Transcriptional regulation of fibronectin gene by phorbol myristate acetate in hepatoma cells: a negative role for NF-кB. Journal of Cellular Biochemistry 76 437-451.

Levenson AS, Kwaan HC, Svoboda KM, Weiss IM, Sakurai S \& Jordan VC 1998 Oestradiol regulation of the components of the plasminogen-plasmin system in MDA-MB-231 human breast cancer cells stably expressing the oestrogen receptor. British Journal of Cancer 78 88-95.

Lindgren PR, Cajander S, Backstrom T, Gustafsson JA, Makela S \& Olofsson JI 2004 Estrogen and progesterone receptors in ovarian epithelial tumors. Molecular and Cellular Endocrinology 221 97-104.

Mercier I, Colombo F, Mader S \& Calderone A 2002 Ovarian hormones induce TGF-beta(3) and fibronectin mRNAs but exhibit a disparate action on cardiac fibroblast proliferation. Cardiovascular Research $\mathbf{5 3}$ 728-739.

Meyers MJ, Sun J, Carlson KE, Marriner GA, Katzenellenbogen BS \& Katzenellenbogen JA 2001 Estrogen receptor-beta potency-selective ligands: structure-activity relationship studies of diarylpropionitriles and their acetylene and polar analogues. Journal of Medicinal Chemistry $\mathbf{4 4}$ 4230-4251.

Moll F, Katsaros D, Lazennec G, Hellio N, Roger P, Giacalone PL, Chalbos D, Maudelonde T, Rochefort H \& Pujol P 2002 Estrogen induction and overexpression of fibulin-1C mRNA in ovarian cancer cells. Oncogene 21 1097-1107.

Mosselman S, Polman J \& Dijkema R 1996 ER beta: identification and characterization of a novel human estrogen receptor. FEBS Letters 392 49-53.

Nash JD, Ozols RF, Smyth JF \& Hamilton TC 1989 Estrogen and anti-estrogen effects on the growth of human epithelial ovarian cancer in vitro. Obstetrics and Gynecology 73 1009-1016.

Ogawa S, Inoue S, Watanabe T, Hiroi H, Ori-mo A, Hosoi T, Ouchi Y \& Muramatsu M 1998 The complete primary 
structure of human estrogen receptor beta (hER beta) and its heterodimerization with ER alpha in vivo and in vitro. Biochemical andBiophysical Research Communications 243 122-126.

O'Lone R, Frith MC, Karlsson EK \& Hansen U 2004 Genomic targets of nuclear estrogen receptors. Molecular Endocrinology 18 1859-1875.

Papadimitriou CA, Markaki S, Siapkaras J, Vlachos G, Efstathiou E, Grimani I, Hamilos G, Zorzou M \& Dimopoulos MA 2004 Hormonal therapy with letrozole for relapsed epithelial ovarian cancer. Long-term results of a phase II study. Oncology 66 112-127.

Ponglikitmongkol M, Green S \& Chambon P 1988 Genomic organization of the human oestrogen receptor gene. EMBO Journal 11 3385-3388.

Pujol P, Rey JM, Nirde P, Roger P, Gastaldi M, Laffargue F, Rochefort H \& Maudelonde T 1998 Differential expression of estrogen receptor-alpha and -beta messenger RNAs as a potential marker of ovarian carcinogenesis.

Cancer Research 58 5367-5373.

Rowlands C, Krishnan V, Wang X, Santostefano M, Safe S, Miller WR \& Langdon SP 1993 Characterisation of the aryl hydrocarbon receptor and aryl hydrocarbon responsiveness in human ovarian carcinoma cell lines. Cancer Research 53 1802-1807.

Rutherford T, Brown WD, Sapi E, Aschkenazi S, Munoz A \& Mor G 2000 Absence of estrogen receptor-beta expression in metastatic ovarian cancer. Obstetrics and Gynecology 96 417-421.

Sampath D, Winneker RC \& Zhang Z 2001 Cyr61, a member of the $\mathrm{CCN}$ family, is required for MCF-7 cell proliferation: regulation by 17 beta-estradiol and overexpression in human breast cancer. Endocrinology 142 2540-2548.
Seth P, Porter D, Lahti-Domenici J, Geng Y, Richardson A \& Polyak K 2002 Cellular and molecular targets of estrogen in normal human breast tissue. Cancer Research 62 4540-4544.

Shang Y, Hu X, DiRenzo J, Lazar MA \& Brown M 2000 Cofactor dynamics and sufficiency in estrogen receptorregulated transcription. Cell $103843-852$.

Slotman BJ \& Rao BR 1988 Ovarian cancer (review): etiology, diagnosis, prognosis, surgery, radiotherapy, chemotherapy and endocrine therapy. Anticancer Research 8 417-434.

Stauffer SR, Coletta CJ, Tedesco R, Nishiguchi G, Carlson K, Sun J, Katzenellenbogen BS \& Katzenellenbogen JA 2000 Pyrazole ligands: structure-affinity/activity relationships and estrogen receptor-alpha-selective agonists. Journal of Medicinal Chemistry 43 4934-4947.

Tora L, Gaub MP, Mader S, Dierich A, Bellard M \& Chambon P 1988 Cell-specific activity of a GGTCA half-palindromic oestrogen-responsive element in the chicken ovalbumin gene promoter. EMBO Journal 7 3771-3778.

Tsai MS, Bogart DF, Li P, Mehmi I \& Lupu R 2002 Expression and regulation of Cyr61 in human breast cancer cell lines. Oncogene 21 964-973.

Woodward TL, Mienaltowski AS, Modi RR, Bennett JM \& Haslam SZ 2001 Fibronectin and the alpha(5)beta(1) integrin are under developmental and ovarian steroid regulation in the normal mouse mammary gland. Endocrinology 142 3214-3222.

Zoubine MN, Weston AP, Johnson DC, Campbell DR \& Banerjee SK 1999 2-Methoxyestradiol-induced growth suppression and lethality in estrogen-responsive MCF-7 cells may be mediated by down regulation of $\mathrm{p} 34 \mathrm{cdc} 2$ and cyclin B1 expression. International Journal of Oncology 15 639-646. 